\title{
ДОСЛІДЖЕННЯ ЯКІСНОГО СКЛАДУ МОЛОКА КОРІВ УКРАЇНСЬКОЇ БУРОЇ МОЛОЧНОЇ ПОРОДИ
}

\author{
Ю. І. СКЛЯРЕНКО ${ }^{1}$, Т. О. ЧЕРНЯВСЬКА ${ }^{2}$, Л. В. БОНДАРЧУК ${ }^{2}$ \\ ${ }^{1}$ Iнститут сільського господарства Північного Сходу НААН (Сад, Украӥна) \\ ${ }^{2}$ Сумський національний аграрний університет (Суми, Україна) \\ sklyrenko9753@rambler.ru
}

В статті вивчений якісний склад молока корів украӥнської бурої молочної породи в розрізі господарств та генеалогічного походження. Досліджено вміст в молочі корів жиру, білка, казеїну, лактози та кількість соматичних клітин. Встановлена різниия за якісним складом молока корів залежно від господарства та генеалогічного походження тварин.

Ключові слова: порода, молочна продуктивність, вміст білку, вміст жиру, казеїн, лактоза

\section{RESEARCH OF THE QUALITATIVE COMPOSITION OF MILK OF COWS OF UKRAINIAN BROWN DAIRY BREED}

${ }^{1}$ Y. I. Sklyarenko, ${ }^{2}$ T. O. Chernyavska, ${ }^{2}$ L. V. Bondarchuk

${ }^{1}$ Institute of Agriculture of Northern East of NAAS (Sad, Ukraine)

${ }^{2}$ Sumy National Agrarian University (Sumy, Ukraine)

The aim of the research is to study the qualitative composition of milk of cows of Ukrainian brown dairy breed in terms of households and in the context of genealogical descent. Studies have been conducted on the content of fat, protein, casein, lactose and somatic cell count in cow milk. Established difference of qualitative composition of milk of cows depending on the households and on the genealogical origin of the animals.

Key words: breed, milk productivity, protein content, fat content, casein, lactose

ИССЛЕДОВАНИЯ КАЧЕСТВЕННОГО СОСТАВА МОЛОКА КОРОВ УКРАИНСКОЙ БУРОЙ МОЛОЧНОЙ ПОРОДЫ

${ }^{1}$ Ю. И. Скляренко, ${ }^{2}$ Т. А. Чернявская, ${ }^{2}$ Л. В. Бондарчук

${ }^{1}$ Институт сельского хозяйства Северного Востока НААН (Сад, Украина)

${ }^{2}$ Сумской начиональный аграрный университет (Сумы, Украина)

В статье изучен качественньй состав молока коров украинской бурой молочной породь в разрезе хозяйств и генеалогического происхождения. Исследовано содержание в молоке коров жира, белка, казеина, лактозы и количество соматических клеток. Установлена разница по качественному составу молока коров в зависимости от хозяйства и генеалогического происхождения животных.

Ключевые слова: порода, молочная продуктивность, содержание белка, содержание жира, казеин, лактоза

Вступ. На сучасному етапі в результаті використання швіцької породи за відносно короткий період часу в Україні створена нова високопродуктивна порода великої рогатої худоби. Українська бура молочна порода створена шляхом простого відтворного схрещування лебединської худоби із швіцькою породою західноєвропейської та північноамериканської селекції $[3,7]$.

Дослідження, проведені Ладикою В. І. [5], свідчать, що за вмістом жиру в молоці корови швіцької породи перевершували лебединських на $0.3 \%$. За вмістом білка в молоці перевагу мали чистопородні швіцькі та напівкровні тварини, де рівень цієї складової становить 3.35\% проти $3.33 \%$ у молоці тварин з 75\% поліпшуючої породи. Кількість казеїну в молоці корів лебединської породи становила 2.66\%, а в молоці швіцьких корів 2.72\%. У молоці напівкров- 
них корів вміст казеїну на $0.06 \%$ більше від швіцьких. У корів з 75\% крові за швіцькою породою цей показник менший за показники швіцьких та напівкровних на $0.02 \%$ та 0.04\%, відповідно. Для виробництва сиру бажаний вміст казеїну в молоці не нижче від $2.7 \%$. Цьому показнику відповідало молоко, отримане від тварин швіцької породи та помісей.

За даними Приходько М.Ф.[7] тварини української бурої молочної породи переважали аналогів української чорно-рябої молочної породи за вмістом жиру в молоці. Різниця над аналогами СВТ УЧРМП за лактаціями за вмістом жиру в молоці склала $-0,11 \%, 0,09 \%, 0,03 \%$ ( $\mathrm{P}>0,999)$, білка - 0,13\%, 0,06\%, 0,12\% (P>0,999). Кількість жиру і білка синтезованих організмом тварини СВТ УЧРМП за лактаціями дорівнює 339 кг, 375 кг, 405 кг, у корів УБМП 252 кг, 332 кг, 358 кг. Різниця відповідно склала 87 кг, 43 кг, 47 кг (Р>0,999).

Болгова Н.В.[3], пише, що перевагу за величиною надою мають первістки лінії Стретча 143612, Елеганта 148551 і Лайласана 131528. Аналогічно від них одержано і більшу кількість молочного жиру.

Салогубом A.M..[8] встановлено, що на вміст жиру в молоці корів-первісток достовірний вплив чинять паратипові - рік народження $\left(\eta_{x}{ }^{2}=0,062-0,231\right)$ й отелення $\left(\eta_{x}{ }^{2}=0,046-0,277\right)$ тварин, та генотипові фактори - племінна цінність батька $\left(\eta_{x}{ }^{2}=0,054-0,218\right)$, СПЦ матері за надоєм ( $\left.\eta_{x}{ }^{2}=0,135-0,303\right)$, CI батька матері $\left(\eta_{x}{ }^{2}=0,037-0,123\right)$, CI матері батька $\left(\eta_{x}{ }^{2}=0,085-0,116\right), \mathrm{CI}$ батька батька $\left(\eta_{x}{ }^{2}=0,091-0,143\right)$, лінія батька $\left(\eta_{x}{ }^{2}=0,047-0,153\right)$ та лінія матері $\left(\eta_{x}{ }^{2}=0,084-\right.$ $0,109)$, урахування яких у процесі добору та підбору буде сприяти ефективній селекції порід.

Подібні данні наводять і інші вітчизняні науковці $[1,2,9]$.

При селекції певних фізіологічних ознак важливо знати ступінь і напрямок їх зв’язку з іншими господарсько-корисними особливостями. Визначення кореляції дозволяє виявити ці взаємозв'язки, що необхідно для подальшого селекційного удосконалення порід та типів молочної худоби. Коефіцієнти кореляції між величиною надою та вістом жиру в молоці у розрізі лактацій коливалися від невірогідно позитивного до невірогідно негативного значень у тварин обох порід. Аналогічна тенденція спостерігалася між надоєм та кількістю сухої речовини, сухого знежиреного молочного залишку. Достовірні негативні кореляційні зв'язки спостерігалися між надоєм та вмістом білку в молоці, вмістом казеїну[4].

Важливим показником якості молока - є вміст соматичних клітин в молоці. БратушкаР.В.[4] наводить дані, що найбільш істотно на вміст соматичних клітин у молоці впливає батько.

За період з моменту апробації породи в господарствах з розведення української бурої молочної породи не проводились детальні дослідження якості молока. Тому вирішення питання визначення якості молока корів української бурої молочної породи є на нашу думку актуальним питанням.

Матеріал та методи досліджень. Дослідження проведені на поголів’ї української бурої молочної породи в умовах Державного підприємства «Дослідне господарство Інституту сільського господарства Північного Сходу НААН» Сумського району(n=113), ТДВ «Маяк» Тростянецького району (n=173), ДП ДГ АФ «Надія» Інституту сільського господарства Північного Сходу НААН Роменського району(n=85). Молочну продуктивність оцінювали шляхом щомісячних контрольних доїнь з відбором проб молока. Якісні показники визначали в лабораторії колишнього Сумського державного селекційного центру на обладнанні фірми Bentley. Досліджували відсоток жиру, відсоток білку, в т.ч. казеїну, відсоток сухої речовини, сухого знежиреного залишку, вміст соматичних клітин. Біометричну обробку результатів проводили за загальноприйнятою методикою (Плохинського М.О., 1969 р.), з використанням П3 Statistica 6.0.

Результаті досліджень. Забезпечення подальшого генетичного прогресу вітчизняних порід обумовлює необхідність постійного моніторингу селекційно-генетичної ситуації і адаптаційних процесів, як в окремих заводських стадах, так і в породах в цілому з метою встановлення певних закономірностей, виявлення чинників, котрі впливають на основні господарськи корисні ознаки і пошуку шляхів подальшого їх вдосконалення. 
За останні роки молочна продуктивність тварин української бурої молочної породи в племінних господарствах дещо знизилась (рис. 1).

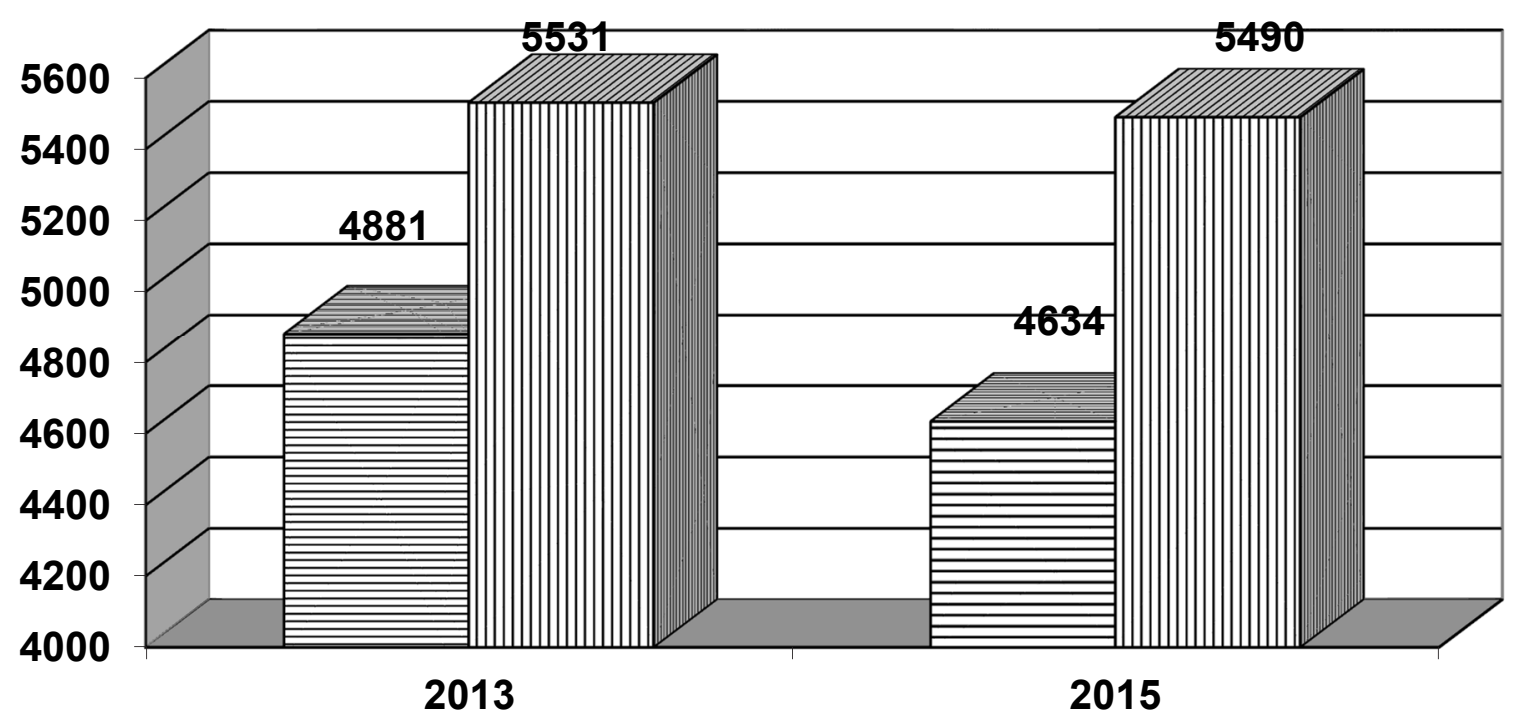

\section{I Лактація ㅇIㄱ Лактація}

Рис. 3. Динаміка змін молочної продуктивності в племінних господарствах з розведення української бурої молочної породи

Аналіз проведених нами досліджень вказує на те, що рівень якісних показників молочної продуктивності у тварин української бурої молочної породи в різних господарствах суттєво відрізняється (табл. 1).

1. Якісні показники молочної продуктивності корів украӥнської бурої молочної породи zосподарств регіону

\begin{tabular}{|c|c|c|c|c|c|c|c|}
\hline \multirow[b]{2}{*}{ Господарство } & \multicolumn{7}{|c|}{ Показники } \\
\hline & $\begin{array}{c}\text { вміст жиру } \\
\text { в мо- } \\
\text { лоці, \% }\end{array}$ & $\begin{array}{l}\text { вміст } \\
\text { казе- } \\
\text { їну, \% }\end{array}$ & $\begin{array}{c}\text { вміст } \\
\text { лак- } \\
\text { този, \% }\end{array}$ & $\begin{array}{l}\text { вміст су- } \\
\text { хої речо- } \\
\text { вини, \% }\end{array}$ & $\begin{array}{c}\text { вміст су- } \\
\text { хого знежи- } \\
\text { реного за- } \\
\text { лишку, \% } \\
\end{array}$ & $\begin{array}{l}\text { вміст } \\
\text { бі- } \\
\text { лку, \% }\end{array}$ & $\begin{array}{l}\text { кількість со- } \\
\text { матичних клі- } \\
\text { тин, тис. } \text { см }^{2}\end{array}$ \\
\hline $\begin{array}{l}\text { ТДВ “МАЯК” } \\
(\mathrm{n}=173)\end{array}$ & $\begin{array}{c}3,98 \\
\pm 0,06\end{array}$ & $\begin{array}{c}3,31 \\
\pm 0,03\end{array}$ & $\begin{array}{c}4,67 \\
\pm 0,02\end{array}$ & $\begin{array}{c}13,1 \\
\pm 0,08\end{array}$ & $\begin{array}{l}9,13 \\
\pm 0,03\end{array}$ & $\begin{array}{c}3,55 \\
\pm 0,03\end{array}$ & $\begin{array}{l}596,9 \\
\pm 79,5\end{array}$ \\
\hline $\begin{array}{l}\text { ДП ДГ АФ “На- } \\
\text { дія” ІСГПС } \\
\text { НААН } \\
(\mathrm{n}=85)\end{array}$ & $3,77 \pm 0,05$ & $\begin{array}{c}2,86 \\
\pm 0,02\end{array}$ & $\begin{array}{c}4,72 \\
\pm 0,02\end{array}$ & $\begin{array}{c}12,4 \\
\pm 0,06\end{array}$ & $\begin{array}{c}8,62 \\
\pm 0,03\end{array}$ & $\begin{array}{c}3,13 \\
\pm 0,03\end{array}$ & $\begin{array}{l}748,0 \\
\pm 91,2\end{array}$ \\
\hline $\begin{array}{l}\text { ДП ДГ ІСГПС } \\
\text { НААН }(n=113)\end{array}$ & $3,43 \pm 0,06$ & $\begin{array}{c}2,83 \\
\pm 0,04\end{array}$ & $\begin{array}{l}4,68 \\
\pm 0,03\end{array}$ & $\begin{array}{c}12,4 \\
\pm 0,11\end{array}$ & $\begin{array}{c}8,95 \\
\pm 0,06\end{array}$ & $\begin{array}{l}3,10 \\
\pm 0,05\end{array}$ & $\begin{array}{l}773,2 \\
\pm 91,2\end{array}$ \\
\hline
\end{tabular}

За всіма основними якісними показниками перевагу мали тварини господарства ТДВ «Маяк». Вони достовірно переважали корів ДП ДГ АФ «Надія» ІСГПС НААН та ДП ДГ ІСГПС НААН відповідно: за вмістом жиру - на 0,21 \%(P<0,001) та 0,55 \% (P<0,001); вмістом білку - на $0,42 \%(\mathrm{P}<0,001)$ та $0,45 \%(\mathrm{P}<0,001)$; вмістом казеїну - на $0,45 \%(\mathrm{P}<0,001)$ та $0,48 \%$ $(\mathrm{P}<0,001)$; сухої речовини - на $0,6 \%(\mathrm{P}<0,001)$ та $0,6(\mathrm{P}<0,01)$; сухого знежиреного залишку $0,51 \%(\mathrm{P}<0,001)$ та $0,18(\mathrm{P}<0,05)$. За вмістом лактози в молоці та кількістю соматичних клітин в молоці достовірної різниці не встановлено, хоча необхідно відмітити, що за кількістю соматичних клітин в молоці кращі показники мали тварини ТДВ «Маяк». 
За рівнем молочної продуктивності корови лінії Елеганта 148551 переважають корів відповідно корів ліній - Дістінкшна 159523 на 130 кг, Вігата 083352 на 270 кг, Стретча 143612 на 450 кг.

Нами проаналізовані якісні показники молока від корів різних генеалогічних ліній української бурої молочної породи в умовах Державного підприємства Дослідного господарства Північного Сходу НААН (табл. 2). Основними лініями української бурої молочної породи в господарстві $\epsilon$ - лінії Елеганта 148551, Дістінкшна 159523 та Ладді 125640.

2. Якісні показники молочної продуктивності корів украӥнської бурої молочної породи різних генеалогічних ліній

\begin{tabular}{|c|c|c|c|c|c|c|c|}
\hline \multirow[b]{2}{*}{ Генеалогічні лінії } & \multicolumn{7}{|c|}{ Показники } \\
\hline & $\begin{array}{c}\text { вміст } \\
\text { жиру в } \\
\text { молоці, \% }\end{array}$ & $\begin{array}{c}\text { вміст } \\
\text { казе- } \\
\text { їну, \% }\end{array}$ & $\begin{array}{c}\text { вміст } \\
\text { лак- } \\
\text { този, \% }\end{array}$ & $\begin{array}{c}\text { вміст су- } \\
\text { хої речо- } \\
\text { вини, \% }\end{array}$ & $\begin{array}{c}\text { вміст су- } \\
\text { хого знежи- } \\
\text { реного за- } \\
\text { лишку, \% }\end{array}$ & $\begin{array}{l}\text { вміст } \\
\text { бі- } \\
\text { лку, \% }\end{array}$ & $\begin{array}{l}\text { кількість со- } \\
\text { матичних клі- } \\
\text { тин, тис. } \text { см² }^{2}\end{array}$ \\
\hline $\begin{array}{l}\text { Дістінкшна } \\
159523(\mathrm{n}=15)\end{array}$ & $3,65 \pm 0,11$ & $3,02 \pm 0,12$ & $4,70 \pm 0,05$ & $12,8 \pm 0,16$ & $9,17 \pm 0,08$ & $\begin{array}{c}3,33 \\
\pm 0,12\end{array}$ & $427,4 \pm 86,6$ \\
\hline $\begin{array}{l}\text { Елеганта } 148551 \\
(\mathrm{n}=50)\end{array}$ & $3,49 \pm 0,06$ & $2,82 \pm 0,04$ & $4,75 \pm 0,04$ & $12,5 \pm 0,11$ & $9,00 \pm 0,06$ & $\begin{array}{c}3,09 \\
\pm 0,05\end{array}$ & $551,7 \pm 80,6$ \\
\hline $\begin{array}{l}\text { Ладді } 125640 \\
(\mathrm{n}=16)\end{array}$ & $3,46 \pm 0,13$ & $2,78 \pm 0,07$ & $4,70 \pm 0,06$ & $12,4 \pm 0,22$ & $8,92 \pm 0,11$ & $\begin{array}{c}3,01 \\
\pm 0,08\end{array}$ & $772,2 \pm 91,2$ \\
\hline
\end{tabular}

Аналізуючи отримані дані, ми можемо відмітити, що за вмістом жиру в молоці перевагу мали корови лінії Дістінкшна 159523. Вони хоч і не достовірно, але переважали тварин ліній Елеганта 148551 та Ладді 125640 відповідно на 0,16 \% та 0,19\%. За вмістом лактози в молоці корів різних ліній суттєвої достовірної різниці не встановлено. Тварини лінії Дістінкшна 159523 достовірно переважали корів ліні Елеганта 148551 та Ладді 125640 за вмістом білка: відповідно на $0,24 \%(\mathrm{P}<0,05)$ та $0,32 \%(\mathrm{P}<0,05)$. За вмістом казеїну вони достовірно переважали корів лінії Ладді 125640 - на $0,24 \%(\mathrm{P}<0,05)$. За вмістом сухої речовини та сухого знежиреного молочного залишку відповідно також перевагу мали тварини лінії Дістінкшна 159523.

Встановлено, що на якісні показники молочної продуктивності вплив чинять генотипові фактори - такі як лінія батька: на вміст жиру в молоці - $\eta_{x}{ }^{2}=1,8 \%$; вміст білку в молоці - $\eta_{x}{ }^{2}=7,3 \%$; вміст казеїну в молоці $-\eta_{x}{ }^{2}=0,6 \%$; вміст лактози в молоці - $\eta_{x}{ }^{2}=1,1 \%$; вміст сухої речовини $\eta_{x}{ }^{2}=2,8 \%$, вміст сухого знежиреного залишку - $\eta_{x}{ }^{2}=2,8 \%$; кількість соматичних клітин $\eta_{x}{ }^{2}=3,4 \%$. Відмічаємо, що достовірного впливу не встановлено, що на нашу думку пов'язано з невеликою кількістю піддослідних тварин.

Висновки. В результаті проведених досліджень встановлено, що рівень якісних показників молочної продуктивності у тварин української бурої молочної породи в різних господарствах суттєво відрізняється. Так вміст жиру в молоці варіює в межах 3,43-3,98\%; вміст білку - 3,10-3,55\%; вміст казеїну - 2,83-3,31\%; вміст сухої речовини - 12,4-13,1\%, сухий знежирений молочний залишок - 8,95-9,13\%.

Встановлена залежність якісних показників молока від лінійного походження. За основними показниками перевагу мають тварини лінії Дістінкшна 159523 (вмістом жиру, білку та казеїну).

\section{БІБЛІОГРАФІЯ}

1. Бабій, Н. М. Господарсько-біологічні особливості чорно-рябої худоби вітчизняної та зарубіжної селекції в умовах західного регіону України : автореф. дис. ... канд. с.-г. наук : 
06.02.01 / Н. М. Бабій ;[Інститут розведення і генетики тварин]. - с. Чубинське Київської області, 2008. - 20 c.

2. Бойко, Ю. М. Оцінка ефективності формування генеалогічної структури української бурої молочної породи : автореф. дис. ... канд. с.-г. наук : 06.02.01 / Ю. М. Бойко ; [Інститут розведення і генетики тварин]. - с. Чубинське Київської області, 2012. - 21 с.

3. Болгова, Н. В. Селекційно-генетична оцінка проміжних генотипів української бурої молочної породи, що створюється : автореф. дис. ... канд. с.-г. наук : 06.02 .01 / Н. В. Болгова ; Херсон, 2009. - 22 с.

4. Братушка, Р. В. Вплив генетичних і паратипових факторів на формування селекційних ознак тварин сумського внутрішньопородного типу української чорно-рябої молочної породи : автореф. дис. ... канд. с.-Г. наук : 06.02.01 / Р. В. Братушка ; [Інститут розведення і генетики тварин]. - с. Чубинське Київської області, 2013. - 19 с.

5. Ладика, В. І. Селекційні аспекти якісного удосконалення популяції лебединської худоби : автореф. дис. ... д-ра с.-г. наук : 06.02.01. / В. І. Ладика ; [Інститут розведення і генетики тварин]. - с. Чубинське Київської області, 1999. - 32 с.

6. Лободна, В. П. Оцінка ефективності селекційного удосконалення стада української червоно-рябої молочної породи : автореф. дис. ... канд. с.-г. наук : 06.02 .01 / В. П. Лобода ; [Ннститут розведення і генетики тварин]. - с. Чубинське Київської області, 2014. - 21 с.

7. Приходько, М. Ф. Оцінка продуктивності та технологічних властивостей молока новостворених порід і типів худоби північно-східного регіону України : автореф. дис. ... канд. с.г. наук : 06.02.04 / М. Ф. Приходько ; [Херсонський державний аграрний університет]. Херсон, 2009. - 22 с.

8. Салогуб, А. М. Селекційно-генетичні аспекти формування скотарства північно-східного регіону України : автореф. дис. ... д-ра с.-г. наук : 06.02.01 / А. М. Салогуб ; [Інститут тваринництва НААН]. - Харків, 2011. - 36 с.

9. Шевченко, А. П. Селекційно-генетичні параметри оцінки тварин сумського внутрішньопородного типу української чорно-рябої молочної породи : автореф. дис. ... канд. с.-г. наук : 06.02.01 / А. П. Шевченко ; [Інститут тваринництва НААН]. - Харків, 2013. - 22 с.

\section{REFERENCES}

1. Babii, N. M. 2008. Hospodarsko-biolohichni osoblyvosti chorno-riaboi khudoby vitchyznianoi ta zarubizhnoi selektsii v umovakh zakhidnoho rehionu Ukrainy : avtoreferat dys. na zdobuttya stupenya k. s.-g. n.:06.02.01. - Economical and biological peculiarities of Black-and-White cattle of domestic and foreign selection in the conditions of Western Ukraine. Chubynske, 20 (in Ukrainian).

2. Boiko, Yu. M. 2012. Otsinka efektyvnosti formuvannia henealohichnoi struktury ukrainskoi buroi molochnoi porody : avtoreferat dys. na zdobuttya stupenya k.s.-g.n. za spetsial'nistyu 06.02.01. - Ukrainian Brown Dairy breed genealogical structure forming efficiency estimation. Chubynske, 21 (in Ukrainian).

3. Bolhova, N. V. 2009. Selektsiino-henetychna otsinka promizhnykh henotypiv ukrainskoi buroi molochnoi porody, shcho stvoriuietsia : avtoreferat dys. na zdobuttya stupenya k. s.-g. n. za spetsial'nistyu 06.02.01. - Plant-breeding-genetic estimation of intermediate genotypes by the Ukrainian borax of suckling breed which is created. Chubynske, 22 (in Ukrainian).

4. Bratushka, R. V. 2013. Vplyv henetychnykh i paratypovykh faktoriv na formuvannia selektsiinykh oznak tvaryn sumskoho vnutrishnoporodnoho typu ukrainskoi chorno-riaboi molochnoi poro-dy : avtoreferat dys. na zdobuttya stupenya k. s.-g. n. za spetsial'nistyu 06.02.01. - Influence of genetic and paratypic factors on the formation of selection traits of Sumy interbreed type of the Ukrainian Black-and-White Dairy breed. Chubynske, 19 (in Ukrainian).

5. Ladyka, V. I. 1999. Selektsiini aspekty yakisnoho udoskonalennia populiatsii lebedynskoi khudo-by : avtoreferat dys. na zdobuttya stupenya d. s.-g. n. za spetsial'nistyu 06.02.01. Seiektion aspects qualitative perfection popuiation of Lebedyn Breed. Chubynske, 32 (in Ukrainian). 
6. Lobodna, V. P. 2014. Otsinka efektyvnosti selektsiinoho udoskonalennia stada ukrainskoi chervono-riaboi molochnoi porody : avtoreferat dys. na zdobuttya stupenya k. s.-g. n. za spetsial'nistyu 06.02.01. - Estimation to efficiency of plant-breeding improvement of herd of the Ukrainian red-and-whate dairy breed. Chubynske, 21 (in Ukrainian).

7. Prykhodko, M. F. 2009. Otsinka produktyvnosti ta tekhnolohichnykh vlastyvostei moloka novo-stvorenykh porid $i$ typiv khudoby pivnichno-skhidnoho rehionu Ukrainy : avtoreferat dys. na zdobuttya stupenya k. s.-g. n. za spetsial'nistyu 06.02.04. - Estimation of productivity and technological properties of milk of newly developed livestock breeds and types in the north-eastern region of Ukraine.. Kherson, 21 (in Ukrainian).

8. Salohub, A. M. 2001. Selektsiino-henetychni aspekty formuvannia skotarstva pivnichnoskhidnoho rehionu Ukrainy : avtoreferat dys. na zdobuttya stupenya d. s.-g. n. za spetsial'nistyu 06.02.04. - Selective and genetic aspects of cattle formation in the North-eastern region of Ukraine. Kharkiv, 36 (in Ukrainian).

9. Shevchenko, A. P. 2013. Selektsiino-henetychni parametry otsinky tvaryn sumskoho vnutrishnoporodnoho typu ukrainskoi chorno-riaboi molochnoi porody : avtoreferat dys. na zdobuttya stupenya k. s.-g. n. za spetsial'nistyu 06.02.04. - Selective and genetic features of animals of Sumy into a pedigree type of the Ukrainian black-and-white dairy breed. Kharkiv, 22 (in Ukrainian).

УДК 636:[591.5+001]

\section{ІСТОРІЯ СТАНОВЛЕННЯ ЕТОЛОГІЇ ЯК НАУКИ ПРО ПОВЕДІНКУ ТВАРИН}

\section{М. В. СЛЮСАР, В.І. КОВАЛЬЧУК, Ю. Л. СЛЮСАРЕНКО}

Житомирський національний агроекологічний університет (Житомир, Украӥна)

slusarnv@ukr.net

Розглянуто питання про еволючію поглядів на «розум» тварин - від альтернативного поняття «інстинкт», який об'єднує всі форми індивідуально-пристосувальної діяльності, до сучасних концепцій, які розцінюють елементарне мислення тварин як особливу ї̈ форму, відмінну від здібності до навчання.

Сучасний етап розвитку етології характеризується не тільки відсутністю єдиної теорії, а й наявністю зв'язків, насамперед із порівняльною психологією й нейрофізіологією.

Ключові слова: розум, інстинкт, генетика поведінки, поведінка, вища нервова діяльність THE HISTORY OF THE FORMATION OF ETHOLOGY AS SCIENCE ON BEHAVIOR OF ANIMALS

\section{N. V. Slusar, V. I. Kovalchuk, Yu. L. Slyusarenko}

Zhytomyr National Agroecological University (Zhytomyr, Ukraine)

The question of the evolution of views on the "mind" of animals - from the alternative concept of "instinct", which brings together all forms of individual adaptive to modern concepts that regard basic thinking of animals as a special form of it, other than the ability to learn.

The current stage of development of ethology characterized not only by the lack of a unified theory, but also the availability of connections, especially from comparative psychology and neurophysiology.

Keywords: intelligence, instinct, genetics of behavior, behavior, higher nervous activity

Розведення і генетика тварин. 2017. Вип. 53 